\title{
Performative functions of genocide trials in Rwanda: Reconciliation through restorative justice?
}

\section{An examination of the convergence of trauma, memory and performance through legal responses to genocide in Rwanda}

'It's always present in me. How can I forget?'

Gloriose Batamuriza

Carla De Ycaza*

\begin{abstract}
This article explores the various legal responses to the genocide in Rwanda through the lenses of trauma, memory and performance, and addresses the question of whether trials as performance and methods of legal recourse including international courts, national prosecutions and traditionally adapted mechanisms of transitional justice such as the gacaca courts are effective in reconciling trauma and establishing collective memory. This piece argues that of the available methods of legal redress in post-genocide Rwanda, the gacaca courts are most effective in performing the function of reconciling trauma and establishing collective memory.
\end{abstract}

* Carla De Ycaza is a Ph.D. Candidate in International Human Rights Law at the Irish Centre for Human Rights, National University of Ireland, Galway, focusing on post-conflict transitional justice in Africa, and holds an M.A. in Human Rights Studies (Columbia University). She is a visiting scholar at the Institute for the Study of Human Rights at Columbia University and is a lecturer in human rights and transitional justice at the Center for Global Affairs at New York University. She also currently serves as Editor in Chief of the Interdisciplinary Journal of Human Rights Law. Research and fieldwork in preparation of this article were conducted in the Kigali and Western Provinces of Rwanda in 2009-2010. Ms. De Ycaza has also worked with civil society organisations in Rwanda, Burundi and the Democratic Republic of the Congo. 


\section{Carla De Ycaza}

\section{Introduction}

In the aftermath of mass atrocity, it is necessary and important for those affected to address the trauma of the victims, and to create a history of memory, ${ }^{1}$ refusing to let denial or the act of forgetting occur. There are many ways to go about doing this. One such way is through legal recourse. Trials are an attempt to transfer the desire of individual victims to seek revenge to the state and official bodies (Minow 1998). Trials also demand accountability and the acknowledgement of wrongs committed. But are trials and legal recourse sufficient for reconciling the trauma inflicted by the perpetrators of mass violence?

Despite the available legal instruments for holding perpetrators of genocide accountable for their actions, such as the International Criminal Tribunals in the former Yugoslavia and Rwanda, and the International Criminal Court, genocide still occurs today and has often gone unpunished. The international community has repeatedly failed to respond effectively to genocide, as is evidenced by the case of Rwanda, ${ }^{2}$ and continues to fail to provide effective remedy today, for instance with the situation in Darfur, despite the evolution of international law and the legally binding genocide convention. What methods of effective remedy can then be provided for victims of genocide?

It is crucial for the process of addressing trauma and developing collective memory to begin the process of reconciliation and rebuilding the country after genocide. ${ }^{3}$ By creating independent judiciary bodies, training new judges and police forces, establishing a constitution, and restoring other failed state structures, the state can maintain law and order based on a legitimate system while seeking reparations for victims of the trauma. Legal reparations must also occur in order to begin the process of reconciliation between the genocidaires and victims of genocide (De Feyter 2005:53-82).

1 See Levy and Sznaider 2002 for an in-depth discussion of creating cosmopolitan historical memory.

2 See Jones 2001.

3 See Van der Kolk and Van der Hart 1991. 


\section{Performative functions of genocide trials in Rwanda}

One of the most effective methods of reconciling the trauma of genocide victims in Rwanda is through the gacaca system, an adaptation of a method of traditional justice previously used in Rwanda. Other options for legal recourse for Rwanda include the International Criminal Tribunal for Rwanda (ICTR), national courts abroad, and classical domestic courts in Rwanda. The embodied practice of performance is present in each of these systems, as each one performs a different function in addressing individual or collective trauma and constructing memory for victims of the genocide. This article argues that gacaca trials as a performative function of transitional justice are the most effective of the available legal responses in determining the collective memory of society and reconciling the trauma of the Rwandan genocide.

\section{Trials as performance}

According to Richard Schechner, quoting Erving Goffman, performance can be defined as 'all the activity of a given participant on a given occasion which serves to influence in any way any of the other participants' (Schechner 2002:23). The people who contribute to the various other performances are the 'audience, observers or co-participants'. Additionally, the 'pre-established pattern of action which is unfolded during a performance and which may be presented or played through on other occasions may be called a "part" or a "routine"'. Performance takes place in 'action, interaction and relation' between people. What is performance also depends on how people receive it, whether they conceive of it as performance (Schechner 2002:31). This can be contrasted with an action as performance. Schechner references Barbara Kirshenblatt-Gimblett's theory that 'to perform is to do, to behave and to show' (Schechner 2002:32). Therefore, an action can be described as performance if it does something, behaves in a certain function and shows something. Trials are one such example, with courtroom procedure as the routine and interaction between the actors, or judges, lawyers, witnesses and accused, as performance.

The function of performance, according to Schechner, is to entertain; to make something that is beautiful; to mark or change identity; to make or foster community; to heal; to teach, persuade or convince; and to deal with the sacred and/or the demonic. Trials as performance here can embody at least several of 


\section{Carla De Ycaza}

these functions, including changing the identity of a community from a past oppressive regime to a more liberal society. The gacaca trials make and foster community by involving all members of society in the legal process. Trials can heal by offering closure to victims in allowing them to face the perpetrators of criminal violence through justice, and by allowing for witness testimony, which can often be cathartic (Teitel 2007). Trials can perform a didactic function, as well, in teaching lessons by providing a record of historical collective memory of the past, staged as collective pedagogy on a public stage. Teitel argues that a trial can provide a shared political knowledge of the past, discrediting the previous political regime while creating lasting records of past state tyranny for future generations to study. Through the construction of a collective narrative, trials tell the story and provide the account of the traumatic events that occurred. ${ }^{4}$ Trials are the archive of hard evidence and the repertoire of testimony as the restoration of order in society (Taylor 2007). Trials can also be persuasive or convincing in terms of exposing the wrongs that were done to maintain order in society, establishing an agreed upon truth in times of controversy in postconflict society.

Trials play an important role in the transition from the past oppressive regime to a liberal society. More literally, as performance in terms of doing an action serving a function, trials involve live practice and embodied testimony, traditionally with the questioning of witnesses by lawyers before a judge. Trials allow for the contextualisation of an individual's trauma within a greater historical narrative, as Caruth (1996:64-66) explains: 'The trauma consists not only in having confronted death but in having survived, precisely, without knowing it... [this] brings into prominent view a larger conception of historical experience.... [and] of a survival exceeding the grasp of the one who survives, engag[ing] a notion of history exceeding individual bounds'. Trials also allow for both victims and perpetrators to remember the trauma and violence, and to tell the truth about what happened through testimony - the importance of which is explained by Herman (1997:1): 'Remembering and telling the truth about terrible events are prerequisites for both the restoration of the social order and for the healing of individual victims. Herman also discusses what Martha Minow explains are the

4 See Felman 2002 for an in-depth discussion of the interaction of law and trauma. 


\section{Performative functions of genocide trials in Rwanda}

fundamental stages of recovery, which trials, especially the gacaca system, help to facilitate: 'The fundamental stages of recovery [from trauma] are establishing safety, reconstructing the trauma story and restoring the connection between survivors and their community' (Minow 1998:3). ${ }^{5}$ Trials help establish safety by holding individual perpetrators accountable for their actions, separating them from the new established government. Trials allow for the reconstruction of the trauma story through the construction of a collective narrative through testimony and the provision of a historical record of the trauma. The gacaca trials in particular allow for the restoration of a connection between survivors and their community through the mechanism of community restorative justice, allowing for all members of the community to take part in the reconciliation and justice process.

One can analyse the Rwandan gacaca trials for genocide specifically as performance. As performance, the gacaca trials take place on a public inclusive stage, involving all members of the community in different roles, with the actors and audience including both perpetrators and victims, in a communal setting on the grass, under the trees in local fora. Prisoners are brought before tribunals composed of people of integrity within the community, as elected by the inhabitants of cells, sectors, communes and prefectures (Uvin no date:2). Members of the entire community are present and act as a 'general assembly', discussing the alleged acts, providing testimony and counter-testimony, argument and counter-argument.

In his video testimony and interview, Mr. Abraham Rwamfizi, a Rwandan man accused of committing genocide, referred to the gacaca proceedings as a 'presentation'. The woman whose husband Rwamfizi killed, Ms. Faissa Mukabazimya, referred to it also as a 'presentation' (Aghion 2004). In a videotaped speech to the community at a pre-gacaca meeting, Mr. Jean Marie Mbarushimana, General Prosecutor of the Rwandan gacaca courts, explained the role of the community in the gacaca judicial process: 'You will be both prosecutor and lawyer...You will be judges' (Aghion 2002). That is to say, the people in the community who were victims of the genocide will be trying their

5 See also Herman 1997. 


\section{Carla De Ycaza}

neighbours, the genocidaires, for these crimes, participating in the performance as actors, playing multiple roles. This recalls Hannah Arendt's description of the Eichmann trial in Eichmann in Jerusalem as being theatrical, performed on the courtroom stage with participants in the trial as actors (Arendt 1992:4). The role of the gacaca trial process is to establish a narrative of collective memory of the community regarding the trauma of the genocide, involving as many actors within the community as possible, each playing their own role in the justice process.

In his text Cities of the Dead, Joseph Roach brings up several interesting and relevant points regarding the convergence of trauma and memory with performance. He discusses the embodiment of memory in and through performance. He states 'The social processes of memory and forgetting, familiarly known as culture, may be carried out by a variety of performance events...to perform in this sense means to bring forth, to make manifest, and to transmit. To perform also means, though often more secretly, to reinvent...this approach necessarily requires movement across conventional disciplinary categories and sometimes against their grain' (Roach 1996:xi-xii). This is particularly interesting to consider in the discussion of trials as performance, since the memory of the trauma of the genocide in Rwanda is being carried out through the performance of the trial, in whichever form, though some more effective than others, bringing forth testimony, transmitting the trauma of the victims through testimony to create a collective narrative of memory of the events that transpired. ${ }^{6}$ Certain trial processes help to reinvent the system and the country more effectively than others, particularly the gacaca trials, which do require a movement away from the established international and national criminal trial processes in Rwanda towards something that is seemingly against their grain, but more in line with traditional local justice in the country, which does allow for greater reinvention and rebirth of society.

Roach asks the questions of whose history and whose memory when discussing the performance and transmission of memory (Roach 1996:7). This is particularly important to consider when evaluating legal trial systems, since

6 See Connerton 1989 for a discussion on the function of collective memory. 


\section{Performative functions of genocide trials in Rwanda}

whose history and memory are being transmitted through the performance of the trial is what determines the trial's effectiveness in achieving the full functions of the performance previously discussed. Schechner also asks, at the end of his introduction on performance studies, several questions to evaluate the effectiveness of the performance of events: 'How is an event deployed in space and disclosed in time? What special clothes or objects are put to use? What roles are played and how are these different, if at all, from who the performers usually are? How are the events controlled, distributed, received, and evaluated?' (Schechner 2002:42). These questions can be used to evaluate the various methods of legal recourse in post-genocide Rwanda as performance, including the gacaca process previously discussed.

\section{Evaluating the performative value and functions of various methods of legal recourse}

In the aftermath of the Rwandan genocide, many cases have been brought against perpetrators of the Rwandan genocide in various fora, including local Rwandan courts, the international criminal tribunal and third party courts. ${ }^{7}$ So far, one of the best methods of reconciling the trauma of genocide victims and documenting collective memory is the gacaca system. By examining the various methods of legal response to genocide in Rwanda, and the success and failure of the gacaca system in Rwanda for trying crimes of genocide, one must conclude that although there are significant setbacks with the gacaca system, of the current available transitional justice mechanisms present, it most effectively performs the function of reconciling and rebuilding the country in postgenocide Rwanda.

\section{The International Criminal Tribunal for Rwanda (ICTR)}

On November 8, 1994, the Security Council adopted Resolution 955 to establish the International Criminal Tribunal for Rwanda in order to prosecute those responsible for genocide and other violations of international law. The purpose of the ICTR was not only to bring peace and reconciliation to Rwanda, but also

7 See Gourevitch 1998 for more regarding the genocide itself. 


\section{Carla De Ycaza}

to ensure that violations of international peace and security would be 'halted and effectively redressed' (Stover and Weinstein 2004:52). Originally, the UN scheduled the ICTR to operate on short-term allocations, which deterred many from taking job posts. Posts took a long time to fill, and many prosecutorial positions were filled with academics and members of human rights organisations not familiar with criminal prosecutions (Stover and Weinstein 2004:52). Investigators also were new to this magnitude of crime, and many knew little or nothing about Rwanda's background and culture. Additionally, basic supplies were scarce due to the lack of appropriate representation of the ICTR on the UN Security Council and the UN Secretariat. This lack of supplies led to poorly presented evidence, in addition to otherwise weak prosecution efforts and strategy, as well as poorly trained judges (Stover and Weinstein 2004:53). Although the ICTR has established accountability for the genocide and crimes against many Rwandans by government officials, military officers, political leaders and the administration, there are many problems with the performance and function of the system, as one can see. There is little room for reconciliation in this type of tribunal, as most Rwandans are not directly affected by the trials in the ICTR.

Many believe that the Court is more focused on developing international law than on the potential impact it could have within Rwandan society. The ICTR, unlike the localised grassroots-based gacaca courts, is seen by many Rwandans as a means of developing international law, due to the fact that the court has adopted a primarily western legal approach, and takes place remotely in Tanzania, away from the affected population in Rwanda. According to Longman and Des Forges, trials should be integrated into a broader program of social reconstruction: 'People tend to see [the ICTR] as an activity of the international community conducted primarily for its own benefit, with little relevance to processes of reconciliation in Rwanda' (Stover and Weinstein 2004:63).

The space in which the ICTR takes place, an international stage in Arusha, is one which is far removed from the Rwandan society itself, thus not affecting a change in community identity, nor making or fostering community in Rwanda, since most Rwandans are not aware of the bulk of the proceedings of the court. It can heal by bringing perpetrators to justice, however it is not 


\section{Performative functions of genocide trials in Rwanda}

particularly constructive in healing the community as a whole, as it does not have a direct effect in building a collective narrative of the memory of the trauma of the victims, but rather functions more as a political teaching tool for the international community to develop case law and set precedent. The local actors from Rwanda involved in the genocide either as victims or perpetrators are now called upon to play a greater role of defining precedent for international law. ${ }^{8}$ Events in the ICTR are controlled by the international community, and are received negatively in Rwanda, based on various video testimonies and reports

given. In this sense, when asked whose memory and whose history, it is clear that the history and memory recorded by the ICTR is one of the international community, not the victims of the trauma, thus making it less effective as a form of reconciliation and construction of a collective memory of the trauma.

\section{Classical Rwandan domestic courts}

National courts are the primary forum for criminal prosecutions for genocide, due to their close relationship to the events, victims, perpetrators and witnesses. International law recognises this state jurisdiction; however, in the past, trials at the domestic level have been rare, due to the frequent destruction of judicial systems in post-conflict societies. National courts are not always most effective in trying genocidaires, due to problems of capacity, political will, politicisation, prosecutorial bias, corruption of judges, and the intimidation of witnesses, all due to the state of transition. Trials are most effective if they are carried out in a regime that is regarded as legitimate (Stover and Weinstein 2004:63).

Although Rwanda is a signatory of the Genocide Convention, it had not incorporated genocide as a crime into its law until August of 1996. Special courts in Rwanda were then created in order to try perpetrators of the genocide. By 2002, over 5000 had been tried, including many sentenced to death or life imprisonment. The government continued to detain over 100000 without charge in overcrowded prisons (Stover and Weinstein 2004:65). At current speeds, it would probably take more than a century to finish the trials for all those currently imprisoned in Rwandan jails (Stover and Weinstein 2004:64).

8 See Magnarella 2000 for more on the criticisms and interactions between local courts and opinions and the ICTR. 


\section{Carla De Ycaza}

It is socially, economically, and politically very costly for Rwanda's government and society. Little is being done to help rebuild the Rwandan judicial system itself and most of the international aid is going to fund international legal projects, such as the ICTR, instead.

In this sense, the classic domestic Rwandan courts are failing to perform the function of changing the political identity of the country, since they are still biased politically. These courts cannot make or foster community, as they are extremely backed up, detaining many individuals who have not been tried and are potentially innocent, creating greater animosity between the accused and their accusers, and allowing for a greater divide in society (Aghion 2002 and 2004). These courts therefore also cannot heal the victims or promote reconciliation effectively.

\section{National courts abroad}

In addition to the local judicial response by the gacaca and international legal action by the ICTR, third party trials have occurred abroad to hold individuals accountable for their actions in the Rwandan genocide. One such prosecution occurred in 1999 in Switzerland, and a Rwandan official guilty of violating the Geneva Conventions and laws of war, was sentenced to life imprisonment. This official could not be tried for his crimes of genocide, since there is no domestic genocide law in Switzerland (Stover and Weinstein 2004:67). In 2001, another trial occurred in Belgium, in which two nuns, a physics professor and a businessman were prosecuted for complicity in genocide and crimes against humanity. These individuals could be tried, since genocide is a part of Belgian domestic penal code.

The doctrine of universal jurisdiction allows national courts to try the most severe crimes against humanity, including genocide, despite whether the crimes are committed in the national territory or by government leaders of other states. These third party national prosecutions occur infrequently, and universal jurisdiction is still a developing legal concept; however they still provide effective remedy in certain situations. Similarly, the Alien Tort Statute, although a tool of civil litigation and not criminal prosecution, performs a function of transitional 


\section{Performative functions of genocide trials in Rwanda}

justice by addressing the trauma and memory of survivors by allowing for victims to obtain reparations from perpetrators in a national court outside of Rwanda, in the United States.

\section{ATS litigation}

The Alien Tort Statute (ATS) was enacted by the founding fathers in the Judiciary Act of 1789, conferring original jurisdiction on federal courts when an alien brings suit for a tort that was committed in violation of international law or a treaty of the United States. The ATS was meant to apply to crimes so grievous that the international community would want to adjudicate and eliminate them. The ATS is narrowly tailored to apply only to a small spectrum of cases, such as genocide.

In a 1996 ATS case regarding genocide in Rwanda, Mushikiwabo v. Barayagwiza, defendant Jean Bosco Barayagwiza was one who played a key role in the torture and massacre of thousands of Rwanda's Tutsi minority and moderate members of the Hutu majority. Barayagwiza was a leader of the Rwandan Hutu political party ('the CDR'). The CDR had its own militia, which carried out a plan to exterminate Rwanda's Tutsi population, in conjunction with Rwandan government forces. Plaintiffs' relatives were massacred as a result of the campaign of genocide planned by the defendant and co-conspirators. The plaintiffs were subsequently awarded $\$ 500000$ per relative for pain and suffering, $\$ 1000000$ per relative for punitive damages, and $\$ 5000000$ for each plaintiff.

The ATS allows for reparations for genocide, but still is not an effective tool in achieving reconciliation throughout Rwandan society for victims of mass trauma. It is extremely narrow in scope and is not effective in terms of creating a narrative of collective memory, ${ }^{9}$ as it deals with individual torts in a foreign country and does not affect the general population, but does offer some hope for those seeking monetary compensation, though oftentimes defendants are unable to pay the amount awarded to the victims.

Since cases involving universal jurisdiction, like the Swiss and Belgian cases, are very rare, it is difficult to determine their true performative value and

9 See De Greiff 2006:51-503 on justice, law and reparations. 


\section{Carla De Ycaza}

function, as there are few cases to use as evidence. These courts have similar problems to those of the ICTR, as they are international actors attempting to right the wrongs inflicted on Rwandan victims without offering true healing or rebuilding of Rwandan society. The ATS is sometimes effective in terms of obtaining reparations and monetary compensation; however it does not mark or change identity; make or foster community; or heal. It does offer a didactic function through precedent, showing that genocidaires can be held liable for their actions; however, the statute is so narrowly tailored that even this does not always occur, as oftentimes cases are thrown out for various technical reasons. This still is not the most effective means of reconciling trauma in post-genocide Rwanda through the construction of collective memory.

\section{Gacaca courts}

Gacaca courts are a grassroots legal mechanism adopted by the Rwandan government to respond to the legacies of the country's 1994 genocide. Nationallevel discussions in the 1990s determined that citizen participation in the justice process would be critical for the manifestation of the truth about the genocide and the creation of a conducive environment for reconciliation (Stover and Weinstein 2004:69). Gacaca is modelled after a traditional Rwandan dispute resolution mechanism to involve a large part of the population as either judges or witnesses. One woman, Annonciata Mukanyonga, believes that gacaca is 'where the truth will come out' (Aghion 2004). ${ }^{10}$ Interviewee Welars Muyango believes that through gacaca, the genocidaires 'must be made an example of so that my children and those of others understand that killing is a bad and reprehensible thing. The aim of gacaca is to speed up the trials and empty the prisons, and to involve the community, including the victims, in establishing the truth in order to promote reconciliation (Uvin no date:2). The mission of the gacaca process is to disclose the truth on the events surrounding the 1994 genocide; to speed up genocide trials; to eradicate the culture of impunity; to reconcile and strengthen unity among Rwandans; and to prove the Rwandan society's capacity to solve its own problems (National Service of Gacaca Jurisdictions 2006).

10 Interview with Annonciata Mukanyonga. 


\section{Performative functions of genocide trials in Rwanda}

Gacaca was originally implemented gradually in each of Rwanda's 12 provinces, then expanded to each of the country's districts in November 2002. The courts classify the prisoners, using the legal categories established in the original 1996 law, then decide on the appropriate penalty, applying penalty ranges from the new gacaca law. Those prisoners who confess and ask for forgiveness receive dramatic reductions in penalties. Part of the penalties is transferred into public service to rebuild the community destroyed by the genocide.

A high value is placed on the community's participation in electing judges and deciding the guilt or innocence of the accused. Lawyers are excluded to give the people a greater sense of community ownership over the process, which contributes to the formation of a collective memory and narrative, as well as to the resolving of both individual and collective trauma. The reparation of damaged properties is to be done by the convicted persons either through restitution of the property looted whenever possible, repayment for the ransacked property, or carrying out work worth the property to be repaired. There is an interesting distinction in the performative function of these gacaca trials compared to the international and domestic criminal trials, since the actors and audience in gacaca are both the perpetrators and the victims, participating in a communal setting on a public inclusive stage. This facilitates truth, justice and reconciliation in the community.

There are also, however, many criticisms of the gacaca process, despite its positive aspects in terms of community restorative justice. ${ }^{11}$ There is no separation between prosecutor and judge, no legal counsel, no legally reasoned verdict, strong pressure toward self-incrimination, and a high potential for major divergences in punishment (Uvin no date:3). Limits to the process of inquiry have impeded the gathering of accurate records. Small populations of survivors are often left to testify in local villages, leaving these few victims susceptible to further violence by perpetrators. The idea of truth telling is relative and not the theoretical judicial truth obtained by inquiry of third party witnesses (Amnesty International 2002). During the local gacaca trials

11 See Harrell 2003:83-96 for specific examples of gacaca as communitarian restorative justice. 


\section{Carla De Ycaza}

in Rwanda, Amnesty International documented the severe overcrowding of detention facilities, the unsanitary conditions, degrading treatment and deaths due to physical abuse, malnutrition and preventable disease in the prisons. Amnesty argues that despite efforts from UN agencies, foreign governments and NGOs to help Rwanda with these local genocide trials, there was a lack of adequate training for jurists involved in the trials, a lack of defence counsel and witnesses for most defendants, lack of time and facilities for the defendants to prepare a defence, lack of impartiality and competence of the judicial officials and a poor courtroom environment, contrary to the International Covenant on Civil and Political Rights (Amnesty International 2002). Therefore, Amnesty International believes that gacaca jurisdiction is not effective.

Some issues raised by Amnesty's investigative report on the gacaca genocide trials in Rwanda include whether the gacaca detention is justifiable, whether these local courts should be used despite their inherent biases and problems of objectivity, and who should conduct the trials. In Constance Morrill's 2001 interviews with incarcerated youth regarding the gacaca process, Candide, an interviewee, stated '[J] ustice will be done. But corruption will absolutely play a part in the Gacaca' (Morrill 2004:79). There has been no conclusion drawn yet regarding these matters.

The gacaca courts allow for the trial as an event to be performed in a public, inclusive space within the community, usually outside on the grass under the trees. Prisoners are recognised by their pink prison uniforms. Community members play the role of the prosecutor, lawyer, judge and witness, as they are allowed to give testimony and render judgment. ${ }^{12}$ Generally speaking, although gacaca has many problems as a system, events are received positively within the community, as the process fosters reconciliation and community building (Aghion 2002). In her 2004 documentary on gacaca, Aghion staged a reconciliation meeting between members of the community, in which one elderly gentleman quoted: 'In Rwanda, we say the family that does not speak dies...when things are revealed, we can turn to the future' (Aghion 2002).

12 See Laub 1992 for a discussion on the importance of bearing witness and truth telling in the psychological healing process of trauma. 


\section{Performative functions of genocide trials in Rwanda}

One empirical study of trauma and reconciliation in Rwanda states: 'An important finding was the significantly greater support for gacaca trials compared with other judicial responses. There are two possible interrelated explanations for this finding. People may have a more positive attitude toward gacaca because they may feel more informed and involved with the process' (Pham, Weinstein and Longman 2004:610). Another study states: 'Most (82\%) of the respondents believe that the acceptance to pay compensation to genocide victims' families is an indication of the desire for reconciliation on the part of the perpetrators of genocide. More than nine out of ten respondents (95.0\%) agree that, to ensure long lasting peace, genocide perpetrators must ask for forgiveness from genocide victims' families. Almost the same percentage (94.3\%) agrees that in order to have sustainable peace, genocide survivors must be prepared to forgive the perpetrators' (Babalola, Karambizi, Sow and Ruzibuka 2003:26).

Gacaca courts allow for the change in identity of perpetrators of genocide by offering forgiveness by the victims, allowing them reintegration into society and construction of a new political all-encompassing identity, with perpetrators and victims living side by side as neighbours, rather than as enemies. In this sense, the gacaca trials also foster community, by allowing all members of the local communities to take part in the performance of the trial. This also allows the victims and perpetrators to heal, to reconcile their trauma, to forgive and be forgiven, and to start fresh. ${ }^{13}$ The trials also teach by disclosing the truth of the events that occurred, offering a collective narrative of the memory of the trauma. Therefore, when asked whose history and whose memory, one can respond that this process does offer a collective history and memory of the community, since both sides offer their story and document it in the proceedings. ${ }^{14}$

13 See Culbertson 1995 for more on truth telling as part of the process of healing trauma and memory after conflict.

14 One caveat to note is that gacaca trials can be seen as victor's justice, since no one from the Rwandan Patriotic Front has yet been convicted. This article argues, however, that the community gacaca justice forum performs the most effective function of the available flawed options in terms of reconciliation of trauma and creation of collective historical memory by bringing together victims and perpetrators in an informal justice setting to address these issues of trauma and memory. 


\section{Carla De Ycaza}

\section{Conclusions}

In light of the failures of the international and domestic courts in dealing with genocide in Rwanda, the gacaca system offers the most effective means of reconciliation for victims of the trauma of genocide and the construction of a collective memory in post-genocide Rwanda. By analysing the performative function of trials in Rwanda, one can conclude that trials offer many positive results in terms of addressing the trauma within a post-conflict society and constructing a collective memory for the victims by hearing both sides of the conflict and rendering judgment on the guilt or innocence of individuals, in order to eliminate the idea of collective guilt of a society, and to help the perpetrators take responsibility for their actions. Trials are a sign of a commitment to redress harms with the application of pre-existing norms. They indicate the administration by a formal system committed to fairness and to opportunities for individuals to be heard in accusation and in defence. There is a 'presumption of innocence, litigation under the adversary system, and the ideal of a government by laws, rather than by persons' (Aghion 2002). Trials imply a belief that massive crimes can be treated as punishable criminal offences by individual perpetrators. Trials transfer the individuals' desire for revenge to the state or official bodies by demanding accountability and punishment. Traditional trials offer a form of closure, but not always reconciliation between the perpetrators and victims. Reconciliation is not the general goal of traditional criminal trials, except in an abstract sense (Aghion 2002). Therefore, combining localised trials with reparations allows for greater healing, one of the functions of trials as performance.

Reparations allow for the restitution of property, repayment for pain/suffering/ punitive damages and the recognition by the perpetrators that they have done wrong towards the victims and can begin to repay them for their losses. ${ }^{15}$ Reparations help heal the wounds of a society and bring together both sides of the conflict by agreeing that wrongs were done and should be acknowledged and reconciled. Once reparations are offered, a society can begin to transform the institutions that made these mass atrocities possible (Minow 1998:91-117).

15 See Barkan 2000:262-282, 308-350 for a more thorough discussion on restitution. 


\section{Performative functions of genocide trials in Rwanda}

Reparations are not only about paying money to the victims, but rather about making repairs to mend the psychological, cultural, social and other wounds inflicted by the trauma on both sides of the conflict. Reparations can bring about a change in the way history is constructed. ${ }^{16}$

In the aftermath of mass violence and genocide, however, according to Peter Uvin (no date:2), 'full, formal justice and complete adherence to human rights standards is [sic] (almost) unattainable'. Trials bring significantly high political, economic, administrative, and social costs. Full justice for the perpetrators of past abuse may incite revenge. The expense to the state of imprisoning and judging tens of thousands of persons according to full standards of criminal law, as well as the cost to the families of the prisoners, is substantial. There is also a need for a large number of competent, unbiased, and well-paid police forces, prosecutors, investigators, judges, etc., which is unlikely to exist in countries with weak educational and administrative systems. Many trials focus on the past, rather than the future, and simplify the conflict by only focusing on the sins of the political losers rather than on the dynamics of the whole system. Often it is not the leaders but the followers who end up being judged, as was originally the case in the Rwandan courts, making the trials not victim-centred but statecentred and politically driven (Uvin no date:2).

In examining the evidence provided in witness testimonies and written accounts, one can conclude that the performative function of the gacaca trials is the most effective of the available legal responses to genocide in Rwanda for determining the collective memory of society and reconciling the trauma inflicted on the victims of the genocide. The gacaca system allows for the change in identity of the community by integrating victims and perpetrators into the justice process, promoting unity and rebirth. The process fosters community by bringing the people of the local villages together in the judicial process of accountability to create a collective narrative of the trauma experienced by the members of the community. This allows the process of healing to begin. Additionally, by promoting accountability and establishing a collective narrative of the trauma and memory of the genocide, the gacaca process offers a didactic or teaching

16 See Barkan and Karn 2006:50-115 on reparations. 


\section{Carla De Ycaza}

function. However, as Longman and Des Forges suggest, trials should also be integrated into a broader program of social reconstruction, utilising various forms of transitional justice in order to achieve reconciliation for the community affected by genocide and other forms of mass violence (Stover and Weinstein 2004:63). As suggested by the International Center for Transitional Justice (2009), a combination of trials, truth-telling commissions and communitybased initiatives, reparations for victims, institutional reform and vetting of corrupt government officials, social reconstruction of schools, parks, etc., local traditional conflict resolution mechanisms, and the construction of memorials/ museums/sites of memory can best contribute to the rebuilding of society and the reconciliation between victims and perpetrators to achieve peace in a postconflict society.

\section{Sources}

Aghion, Anne 2002. Gacaca: Living together again in Rwanda? Video recording. New York, First Run/Icarus Films.

Aghion, Anne 2004. In Rwanda we say: The family that does not speak dies. Video recording. Testimony of Faissa Mukabazimya and Abraham Rwamfizi. Paris, Dominant 7; Gacaca Productions.

Amnesty International 2002. Rwanda: A question of justice. Amnesty International Report, 17 December 2002.

Arendt, Hannah 1992. Eichmann in Jerusalem: A report on the banality of evil. New York, Penguin Books.

Babalola, Stella, Jean Karambizi, Boubacar Sow and John Bosco Ruzibuka 2003. Evaluation of the gacaca promotional campaign in Rwanda: Report of main findings. United States Agency for International Development, February 2003. Available from: $<$ http://pdf.usaid. gov/pdf_docs/PNACT554.pdf>.

Barkan, Elazar 2000. The guilt of nations: Restitution and negotiating historical injustices. New York, Norton.

Barkan, Elazar and Alexander Karn eds. 2006. Taking wrongs seriously: Apologies and reconciliation. Stanford, CA, Stanford University Press.

Caruth, Cathy 1996. Unclaimed experience: Trauma, narrative, and history. Baltimore, MD, Johns Hopkins University Press.

Connerton, Paul 1989. How societies remember. Cambridge, New York, Cambridge University Press. 


\section{Performative functions of genocide trials in Rwanda}

Culbertson, Roberta 1995. Embodied memory, transcendence and telling: Recounting trauma, re-establishing the self. New Literary History, 26 (1), pp. 169-195.

De Feyter, K. 2005. Out of the ashes: Reparation for victims of gross and systematic human rights violations. Antwerpen, Intersentia.

De Greiff, Pablo ed. 2006. The handbook of reparations. Oxford, New York, Oxford University Press.

Felman, Shoshana 2002. The juridical unconscious: Trials and traumas in the twentieth century. Cambridge, MA, Harvard University Press.

Gourevitch, Phillip 1998. We wish to inform you that tomorrow we will be killed with our families: Stories from Rwanda. New York, Picador.

Harrell, Peter 2003. Rwanda's gamble: Gacaca and a new model of transitional justice. New York, Writers Club Press.

Herman, Judith Lewis 1997. Trauma and recovery. New York, Basic Books.

Jones, Bruce D. 2001. Peacemaking in Rwanda: The dynamics of failure. Boulder, CO, Lynne Rienner Publishers.

Laub, Dori 1992. Bearing witness, or the vicissitudes of listening; An event without a witness: Truth testimony and survival. In: Felman, Shoshana and Dori Laub, Testimony: Crises of witnessing in literature, psychoanalysis, and history. New York, Routledge, pp. 57-74 and 75-92, respectively.

Levy, D. and N. Sznaider 2002. Memory unbound: The holocaust and the formation of cosmopolitan memory. European Journal of Social Theory, 5 (1), pp. 87-106.

Magnarella, Paul J. 2000. Justice in Africa: Rwanda's genocide, its courts, and the UN Criminal Tribunal. Contemporary perspectives on developing societies. Aldershot, Hants; Brookfield, VT, Ashgate.

Minow, Martha 1998. Between vengeance and forgiveness: Facing history after genocide and mass violence. Boston, Beacon Press.

Morrill, Constance F. 2004. Reconciliation and the gacaca: The perceptions and peace-building potential of Rwandan youth detainees. The Online Journal of Peace and Conflict Resolution, $6(1)$, pp. 1-66

National Service of Gacaca Jurisdictions 2006. Inkiko-Gacaca. Organic Law No 28/2006 of 27/06/2006. Available from: <http://www.inkiko-gacaca.gov.rw>.

Pham, Phuong N., Harvey M. Weinstein and Timothy Longman 2004. Trauma and PTSD symptoms in Rwanda: Implications for attitudes toward justice and reconciliation. Journal of the American Medical Association, 292 (5), pp. 602-612.

Roach, Joseph 1996. Cities of the dead. New York, Columbia University Press.

Schechner, Richard 2002. Performance studies: An introduction. New York, Routledge. 


\section{Carla De Ycaza}

Stover, Eric and Harvey M. Weinstein eds. 2004. My neighbor, my enemy: Justice and community in the aftermath of mass atrocity. Cambridge, UK, and New York, Cambridge University Press.

Taylor, Diana 2007. Staging truth: Performance and justice. Panelist's presentation at conference on The trial: Stages of truth at The Martin Segal Theater, Graduate Center, City University of New York, 23 April 2007.

Teitel, Ruti 2007. Transitional justice narrative. Opening keynote address at conference on The trial: Stages of truth at The Martin Segal Theater, Graduate Center, City University of New York, 23 April 2007.

Uvin, Peter no date. The introduction of a modernized gacaca for judging suspects of participation in the genocide and the massacres of 1994 in Rwanda: A discussion paper. Second half of report: Propositions for action: Towards a policy of critical support. Available from: $<$ http://fletcher.tufts.edu/humansecurity/pdf/Boutmans.pdf $>$.

Van der Kolk, Bessel A. and Onno van der Hart 1991. The intrusive past: The flexibility of memory and the engraving of trauma. American Imago, 48, pp.425-454. 